\title{
KARAKTERISTIK FISIKOKIMIA DAN SENSORI KOMBUCHA CASCARA (KULIT KOPI RANUM)
}

\author{
[Physicochemical and Sensory Characteristics of the Cascara \\ (Dried Cherries Coffee Peels) Kombucha]
}

\author{
Nurhayati ${ }^{*}$, Sih Yuwanti, dan Aurora Urbahillah \\ Jurusan Teknologi Hasil Pertanian, Fakultas Teknologi Pertanian, Universitas Jember, Jember
}

Diterima 26 Juli 2018 / Disetujui 18 Maret 2020

\begin{abstract}
Kombucha is usually made from tea leaves (Camellia sinensis L.) extracts added with sugar which is fermented with kombucha starter symbiotic culture of bacteria and yeast (SCOBY) containing. Acetobacter xylinum and yeasts including Saccharomyces cerevisiae. In addition to tea leaves, leather dried coffee (cascara) can be harnessed into beverages like tea steeping. This research aims to ferment cascara tea by SCOBY and characterize the cascara kombucha. These research use two factors i.e. cascara concentrations (1 and $2 \% \mathrm{~b} / \mathrm{v}$ ) and fermentation periods (4, 8, 12, and 16 days). Sugar was dissolved into water and boilled, added with the cascara while stirring for about 5 minutes, filtered and cooled to $40^{\circ} \mathrm{C}$, and then fermented in glass jars with faucets indoor without exposure to direct sunlight for 4, 8, 12, and 16 days. The results showed that concentration of cascara and fermentation time affected the characteristics of cascara kombucha. The effectiveness tests showed that cascara kombucha made from $1 \% \mathrm{~b} / \mathrm{v}$ cascara fermented for 8 days resulted in the best and most preferred kombucha. The kombucha characteristics include dissolved solid content of $11.25^{\circ}$ Brix, specific gravity of $1.01 \mathrm{~g} / \mathrm{mL}$, viscosity of $0.9 \mathrm{cP}$, brightness (L) 42.0, reddish color (a) 15.1, yellowish color (b) 28.88, pH 3.43, total acid of 0.29, phenolic of $9.9 \mathrm{mg}$ $\mathrm{GAE} / \mathrm{mL}$. The kombucha flavor was slightly acidic, murky in color, with slight bitter taste.
\end{abstract}

Keywords: cascara, coffee peel, fermentation, kombucha

\begin{abstract}
ABSTRAK
Kombucha biasanya terbuat dari daun teh (Camellia sinensis L.) melalui proses fermentasi yang ditambahkan gula dan starter kombucha yaitu simbiosis bakteri Acetobacter xylinum dan beberapa jenis khamir diantaranya Saccharomyces cerevisiae. Selain daun teh, kulit kopi yang dikeringkan (cascara) dapat dimanfaatkan menjadi minuman seduhan layaknya seduhan teh. Penelitian ini bertujuan mempelajari proses pembuatan fermentasi kombucha cascara dan karakteristik kombucha cascara yaitu karakteristik fisikokimia dan sensori. Penelitian ini dilakukan dengan Rancangan Acak Lengkap dengan dua faktor, yaitu faktor konsentrasi cascara ( 1 dan $2 \% \mathrm{~b} / \mathrm{v}$ ) dan periode fermentasi $(4,8,12$, dan 16 hari). Proses pembuatan dengan merebus air dan gula hingga suhu $\pm 100^{\circ} \mathrm{C}$. Cascara dimasukkan sambil diaduk selama 5 menit, kemudian diangkat dan disaring. Larutan cascara didinginkan sampai suhu berkisar $40^{\circ} \mathrm{C}$, lalu difermentasi dalam wadah toples kaca dengan kran dalam ruangan dan tidak terkena sinar matahari langsung selama 4, 8, 12, dan 16 hari. Hasil penelitian menunjukkan bahwa konsentrasi cascara dan lama fermentasi berpengaruh nyata terhadap karakteris tik fisik (total padatan terlarut, viskositas, dan warna), karakteristik kimia ( $\mathrm{pH}$, total asam, dan total fenolik), dan karakteristik sensori. Berdasarkan uji efektivitas kombucha cascara terpilih adalah konsentrasi 1\% cascara dengan fermentasi selama 8 hari, pada konsentrasi dan lama fermentasi ters ebut kombucha cascara memiliki total fenolik tertinggi dengan $\mathrm{pH}$ dan total asam masih dalam batas aman dikonsumsi serta sensori yang dapat diterima oleh panelis. Kombucha ini mengandung padatan terlarut $11,25^{\circ}$ Brix, berat jenis $1,01 \mathrm{~g} / \mathrm{mL}$, viskositas $0,9 \mathrm{cP}$, kecerahan $\left(L^{*}\right) 42,0$, warna kemerahan $(a+) 15,1$, warna kekuningan $(b+) 28,88$, pH 3,43, asam total $0,29 \%$, fenolik $9,9 \mathrm{mg} \mathrm{GAE} / \mathrm{mL}$, dan rasa yaitu sedikit asam, warna khas cascara (merah kecokelatan), rasa sedikit getir flavonoid.
\end{abstract}

Kata kunci: cascara, fermentasi, kombucha, kulitkopi

\footnotetext{
*Penulis Korespondensi: E-mail: nurhayati.ftp@unej.ac.id
} 


\section{PENDAHULUAN}

Indonesia penghasil kopi terbesar keempat di dunia (ICO, 2017). Produksi kopi di Indonesia sebesar 637.000 ton dengan luas lahan perkebunan 1,1 juta ha (Direktorat Jendral Perkebunan, 2016). Kulit buah kopi merupakan komponen terbesar dari pengolahan buah kopi yang sampai saat ini belum termanfaatkan secara optimal. Menurut Nuraini et al. (2015) buah kopi terdiri dari kulit buah 45\%, mucilage $10 \%$, kulit biji $5 \%$ dan biji kopi $40 \%$. Berdasarkan data diatas maka tersedia limbah berupa kulit kopi sebesar 286.650 ton.

Umumnya limbah kulit kopi dibiarkan menumpuk di sekitar lokasi pengolahan dan menimbulkan bau busuk. Selama ini, kulit buah kopi biasanya hanya dimanfaatkan sebagai pupuk. Pemanfaatan lain kulit buah kopi yaitu sebagai pakan ternak dengan cara ditingkatkan mutunya melalui fermentasi oleh Phanerochaete chrysosporium (Nuraini et al., 2015).

Limbah kulit buah kopi juga berpotensi untuk dimanfaatkan sebagai minuman yang menyegarkan yaitu cascara. Cascara merupakan kulit kopi yang dikeringkan (Pabari, 2014). Seduhan cascara memiliki rasa buah (fruity) dengan perpaduan aroma stroberi dan kismis (Wiser, 2011 dalam Sawab et al., 2017) hingga mawar, cherry, mangga, dan tembakau menyatu dalam seduhan cascara (Muzaifa et al., 2019). Nilai oxygen radical absorbance capacity (ORAC) cascara sebesar $22.070 \mu \mathrm{mol}$ TE/100 g 4 kali dari nilai ORAC blueberry dan setara dengan nilai buah goji dan bubuk cabai. Kandungan kafein cascara adalah $226 \mathrm{mg}$ kafein/L. Protocatechuic dan asam klorogenat sebagai senyawa fenolik yang dominan pada cascara yaitu sebesar 85,0 dan 69,6 $\mathrm{mg} / \mathrm{L}$ (Heeger et al., 2017). Selama ini cascara hanya diseduh biasa. Cascara dapat dikembangkan menjadi minuman terfermentasi yang disebut kombucha.

Kombucha merupakan minuman fermentasi larutan daun tinggi fenol (Suhardini dan Zubaidah, 2016) atau media buah seperti salak (Zubaidah et al., 2018), delima (Yavari et al., 2018), apel (Akbarirad et al., 2017) dan anggur (Ayed et al., 2017) yang ditambahkan gula dan difermentasi dengan starter kombucha yaitu simbiosis bakteri Acetobacter xylinum dan beberapa jenis khamir diantaranya Saccharomyces cerevisiae, proses fermentasi dilakukan selama 1-2 minggu (Battikh et al., 2012; Sun et al., 2015). Selama proses fermentasi akan terjadi perubahan sifat fisik dan kimia meliputi kadar gula, kadar alkohol, $\mathrm{pH}$, dan kadar antioksidan (Nguyen et al., 2015). Saccharomyces memecah glukosa membentuk etanol, sedangkan bakteri $A$. xylinum mampu mengoksidasi etanol menjadi asam asetat (Ayuratri dan Kusnadi, 2017). Proses fermentasi memungkinkan dapat meningkatkan total polife- nol bebas akibat aktivitas enzimatis mikroba yang bisa membebaskan senyawa polifenol terkelat sehingga lebih banyak yang terdeteksi selama analisis (Zubaidah et al., 2012).

Fermentasi kombucha dipengaruhi oleh lama fermentasi, konsentrasi teh, jumlah gula dan jumlah starter yang ditambahkan. Selama fermentasi terjadi perubahan sifat fisik dan kimia. Konsentrasi teh berpengaruh terhadap pertumbuhan mikroorganisme kultur kombucha, nilai pH, jumlah gula, dan organoleptik kombucha. Lama fermentasi juga dapat memengaruhi nilai $\mathrm{pH}$, total asam, dan total gula (Falahuddin et al., 2017). Penelitian ini bertujuan mempelajari proses pembuatan kombucha cascara dan mengetahui karakteristik kombucha cascara.

\section{BAHAN DAN METODE}

\section{Bahan}

Bahan pembuatan kombucha cascara adalah kultur kombucha yang diperoleh dari kultur kolektif Laboratorium Kewirausahaan FTP-UNEJ, cascara diperoleh dari Mat Coffee kelompok petani kopi kawasan ljen Bondowoso-Jawa Timur. Bahan lainnya yaitu air minum, gula kristal putih, SCOBY kombucha. Alat yang digunakan untuk analisis fisikokimia meliputi refractometer (ATAGO Master) skala 0-32\%, piknometer $10 \mathrm{~mL}$ (IWAKI), Ostwald viscometer, colour reader minolta CR10 (Konica Minolta Sensing) (Curi et al., 2017).

\section{Fermentasi kombucha cascara}

Sukrosa $10 \%$ (b/v) direbus dengan $3 \mathrm{~L}$ air hingga mendidih kemudian ditambahkan cascara (1 atau $2 \% \mathrm{~b} / \mathrm{v}$ ) sambil diaduk selama 5 menit. Larutan cascara disaring, lalu didinginkan hingga suhu $40^{\circ} \mathrm{C}$. Selanjutnya larutan cascara dimasukkan ke dalam dispenser gelas (toples kaca dengan kran) dan diinokulasi dengan kultur kombucha sebanyak 10\% (b/v). Fermentasi di dalam ruangan dan tidak terkena sinar matahari langsung selama 4, 8, 12, dan 16 hari. Larutan cascara terfermentasi dipisahkan dari kultur kombucha cascara dan dipasteurisasi pada suhu larutan $85^{\circ} \mathrm{C}$ selama 15 menit. Kombucha cascara terpasteurisasi dikemas ke dalam botol, dan dilakukan analisis fisik, kimia, dan sensori.

\section{Analisis fisik dan kimia kombucha cascara}

Kombucha cascara dianalisis sifat fisiknya yang meliputi total padatan terlarut (Bayu et al., 2017), berat jenis (Azizah et al., 2012), viskositas dengan menggunakan metode ostwald (Bayu et al., 2017), warna dengan menggunakan alat colour reader (Curi et al., 2017). Sifat kimia kombucha cascara yang diukur meliputi nilai keasamannya dengan menggunakan $\mathrm{pH}$ meter (Chakravorty et al., 2016), total asam tertitrasi (Bhusari et al., 2013), dan total 
senyawa fenolik dengan menggunakan metode Folin-Ciocalteu (Pure dan Monir, 2016). Data ditampilkan berdasarkan nilai rata-rata beserta nilai standar deviasi. Kombucha cascara juga dievaluasi sifat sensorinya dengan uji pembedaan pada skala 1-5 meliputi parameter warna (kuning-sangat cokelat), aroma asam (tidak asam-sangat asam), tingkat kekeruhan (tidak keruh-sangat keruh), rasa getir pahit (tidak getir-sangat getir), dan rasa asam (tidak asam-sangat asam) menggunakan 15 panelis semi terlatih yang diseleksi dari 30 panelis.

Karakterisasi sensori dilakukan dengan menggunakan panelis terlatih sebanyak 15 orang. Panelis dilatih untuk mengenali karakteristik alami dari kombucha kontrol terhadap parameter warna, aroma, rasa, dan kenampakan. Jumlah panelis terlatih bukan ahli yang digunakan adalah 30 panelis. Sebagaimana yang dijelaskan oleh Howard et al. (2012) bahwa jumlah panelis tidak terlatih (untrained) minimal 75 orang, panelis terlatih (trained) minimal sebanyak 10 orang dan panelis ahli (expert) minimal sebanyak 6 orang. Pada penelitian ini jumlah panelis tidak terlatih sebanyak 30 orang, maka hasil uji organoleptik hanya dapat memberikan gambaran sementara terhadap uji sensori kombucha cascara.

Seleksi panelis didasarkan pada kemampuan panelis yang mampu membedakan karakterisitik kombucha cascara secara sensori paling mirip dengan hasil uji fisikokimia maka panelis tersebut dipilih untuk uji sensori sebenarnya. Uji sensori hedonik menggunakan skala 1-9, skala 1 diartikan sangat tidak suka dan skala 9 sangat suka. Masing-masing uji sensori dilakukan dua kali. Rentang usia panelis yaitu 20-22 tahun, dilakukan dalam bilik uji dan sampel disajikan pada suhu berkisar $28^{\circ} \mathrm{C}$. Penentuan perlakuan terpilih dilakukan dengan menggunakan uji efektivitas dengan pemberian bobot pada masing-masing parameter yang digunakan. Parameter yang digunakan untuk pem-bobotan uji efektivitas meliputi total fenolik, total asam, dan sensori. Nilai pembobotan menggunakan angka relatif 0 hingga 1 dengan pengelompokan menjadi dua kelompok. Kelompok A adalah kelompok untuk kategori semakin tinggi perolehan angka relatif berarti semakin baik. Kelompok B adalah kelompok untuk kategori semakin tinggi perolehan angka relatif berarti semakin rendah. Nilai efektivitas masing-masing variabel ditentukan dengan rumus:

Nilai Efektivitas $=\frac{\text { nilai perlakuan-nilai terendah }}{\text { nilai tertinggi-nilai terendah }}$

Parameter dalam kelompok A jika memiliki nilai terendah berarti nilai terjelek. Sebaliknya, parameter dalam kelompok B jika memiliki nilai tertinggi berarti nilainya terjelek. Nilai hasil semua parameter dihitung dengan menggunakan rumus sebagai berikut:
$\mathrm{NH}=$ nilai efektivitas $\times$ bobot normal parameter

Nilai hasil $(\mathrm{NH})$ tertinggi dari penjumlahan semua nilai hasil semua parameter. Kombinasinya pada masing-masing perlakuan dinyatakan sebagai perlakuan yang terbaik/terpilih.

\section{HASIL DAN PEMBAHASAN}

\section{Total padatan terlarut kombucha cascara}

Total padatan terlarut kombucha cascara berkisar antara $8,82-13,75^{\circ}$ Brix (Gambar 1). Peningkatan penambahan cascara menghasilkan peningkatan total padatan kombucha cascara $(\alpha<0,05)$. Total padatan terlarut menunjukkan kandungan bahanbahan yang terlarut dalam larutan. Komponen yang terkandung pada cascara terdiri atas komponen yang larut air seperti fruktosa, glukosa, protein, dan kafein (Heeger et al., 2017).

Semakin lama fermentasi kombucha cascara menghasilkan total padatan terlarut yang semakin menurun $(\alpha \leq 0,05)$. Hal ini mengindikasikan adanya aktivitas dan pertumbuhan mikroba yang mendegradasi substrat seperti gula dan kandungan zat terlarut pada cascara untuk metabolismenya. Napitupulu et al. (2015) menjelaskan bahwa peningkatan mikroba diiringi dengan penurunan jumlah substrat karena dikonsumsi untuk metabolisme mikroorganisme sel sehingga nilai total padatan terlarut semakin menurun.

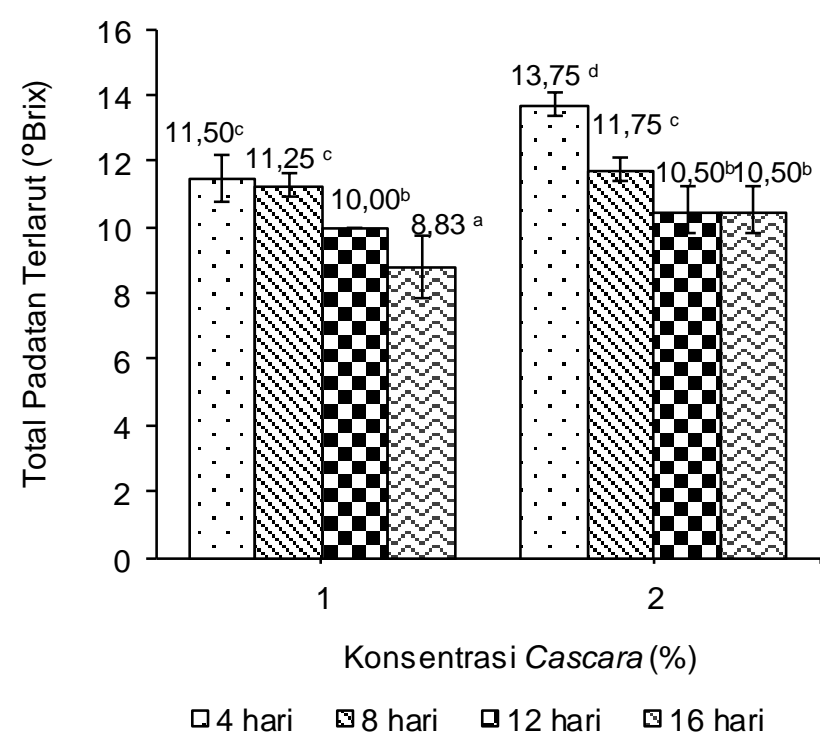

Gambar 1. Nilai total padatan terlarut kombucha cascara 


\section{Berat jenis kombucha cascara}

Berat jenis kombucha cascara berkisar antara 0,99-1,03 $\mathrm{g} / \mathrm{mL}$ (Gambar 2). Berat jenis kombucha cascara lebih tinggi pada penambahan cascara $2 \%$. $\mathrm{Hal}$ ini berhubungan dengan total padatan terlarut yang semakin tinggi dengan semakin banyak cascara yang ditambahkan.

Semakin lama proses fermentasi menghasilkan berat jenis kombucha cascara yang semakin kecil seiring pula dengan total padatan yang menurun. Selama proses fermentasi, mikroba mendegradasi substrat seperti sukrosa dan zat terlarut lainnya (fruktosa, glukosa, protein, lemak dan kafein) sehingga total padatan menurun dan berakibat pula terhadap penurunan berat jenis. Keberadaan $S$. cerevisiae akan mengonversi gula menjadi alkohol dan menstimulasi pertumbuhan Acetobacter xylinum untuk mengonversi alkohol menjadi asam asetat. Demikian pula sebaliknya, asam asetat akan menstimulasi pertumbuhan $S$. cerevisiae untuk menghasilkan etanol. Pertumbuhan sinergis tersebut terus berlangsung hingga keberadaan substrat habis (Pratiwi et al., 2012; Chu dan Chen, 2006). Adanya pembentukan asam asetat dan etanol dari proses degradasi substrat (sukrosa dan kandungan zat terlarut lainnya) oleh kultur kombucha menyebabkan berat jenis kombucha juga menurun.

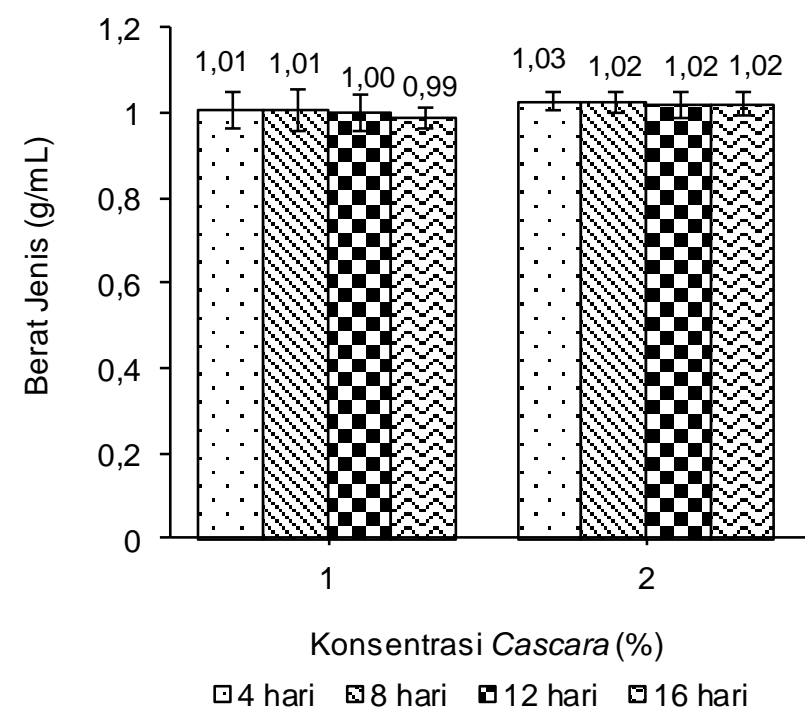

Gambar 2. Nilai berat jenis kombucha cascara

\section{Viskositas kombucha cascara}

Viskositas kombucha cascara berkisar antara 0,88-0,98 cP (Gambar 3). Kombucha cascara dengan penambahan cascara $2 \%$ memiliki viskositas lebih tinggi dibandingkan dengan penambahan cascara $1 \%$. Penambahan cascara yang semakin banyak akan menyebabkan total padatan terlarut semakin tinggi dan berat jenisnya juga meningkat serta berakibat nilai viskositas juga meningkat. Menurut Setianto et al. (2014) jumlah padatan memengaruhi viskositas cairan. Semakin lama fermentasi menunjukkan penurunan viskositas kombucha cascara. Hal ini mengindikasikan adanya aktivitas mikroba dalam mendegradasi sukrosa dan kandungan zat terlarut pada media kombucha cascara sehingga total padatan terlarut menurun akibatnya viskositas juga menurun.

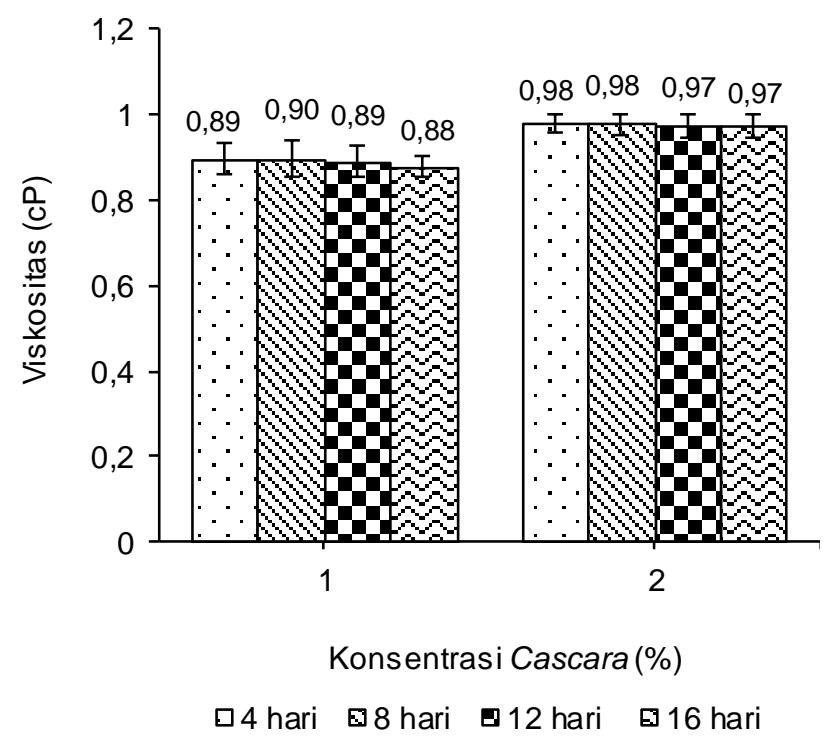

Gambar 3. Nilai viskositas kombucha cascara

\section{Nilai Warna (L, a, b) kombucha cascara}

Kombucha dengan penambahan cascara 2\% menghasilkan tingkat kecerahan (lightness/L) yang lebih rendah dibandingkan pada kombucha dengan penambahan cascara 1\% (Gambar 4). Hal ini diakibatkan adanya pigmen pada cascara yaitu alfa diketon yang berkonstribusi terbentuknya warna cokelat (Soeroso et al., 2017). Semakin banyak penambahan cascara menyebabkan kandungan pigmen alfa diketon juga semakin banyak. Begitu juga dengan nilai warna $(\mathrm{a}+)$, semakin banyak penambahan cascara maka nilai warna $(\mathrm{a}+)$ pada kombucha dengan penambahan cascara 2\% semakin tinggi (Gambar 5). Nilai warna $(b+)$ kombucha cascara berkisar antara 14,13 sampai 15,85 (Gambar 6). Penambahan cascara yang lebih banyak menghasilkan warna kombucha cascara lebih dominan cokelat kemerahan, sehingga nilai warna $(b+)$ kombucha dengan penambahan cascara $2 \%$ lebih rendah dibandingkan kombucha dengan penambahan cascara $1 \%$.

Semakin lama fermentasi menghasilkan tingkat kecerahan kombucha cascara yang semakin meningkat, sedangkan nilai warna $(\mathrm{a}+)$ dan nilai warna $(b+)$ menurun $(a<0,05)$. Hal ini karena diduga akibat keberadaan senyawa alfa diketon pada cascara yang menyebabkan warnanya cokelat sebagai akibat penguraian antosianin kulit kopi selama proses 
pengeringan (Soeroso et al., 2017). Senyawa lain yang berperan dalam pembentukan warna kombucha cascara adalah kandungan tanin yang memberikan warna kuning kegelapan (Mawardi et al., 2016; Lisan, 2015). Senyawa-senyawa tersebut selama fermentasi mengalami kerusakan akibat $\mathrm{pH}$ yang rendah sehingga terbentuk warna semakin cerah pudar (Wistiana dan Zubaidah, 2015; Ayuratri dan Kusnadi, 2017). Keberadaan bakteri dan yeast seperti Acetobacter sp, Lactobacillus sp, dan Saccharomyces sp dapat memproduksi enzim eksternal berupa enzim tannase yang mampu mendegradasi tanin sehingga warna kombucha cascara semakin cerah pudar (Anwar, 2013; Wulandari, 2018) begitu pula dengan nilai warna $(a+)$ serta nilai warna $(b+)$ yang menurun.

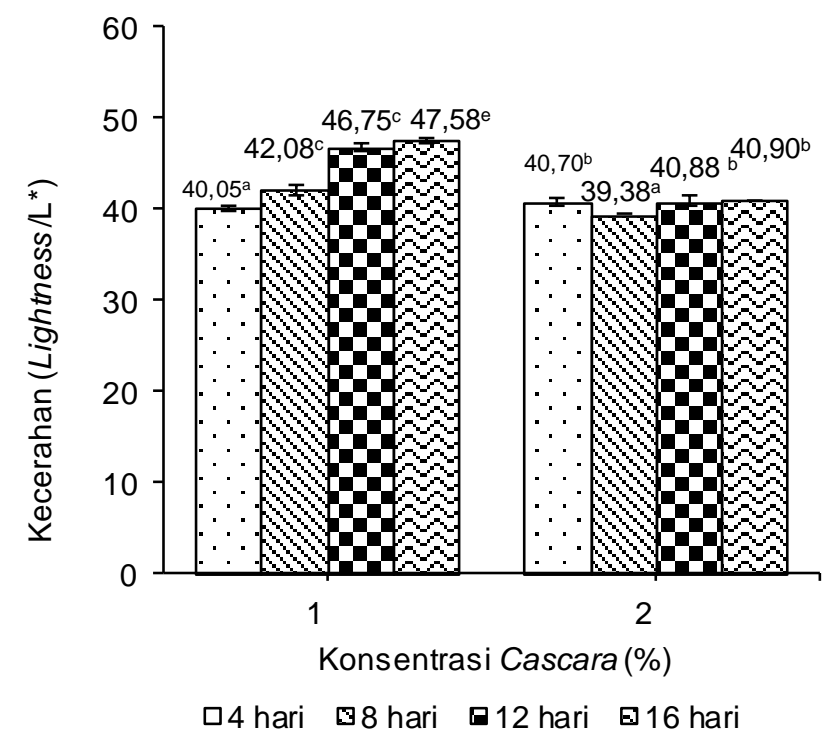

Gambar 4. Nilai kecerahan (lightness/L) kombucha cascara

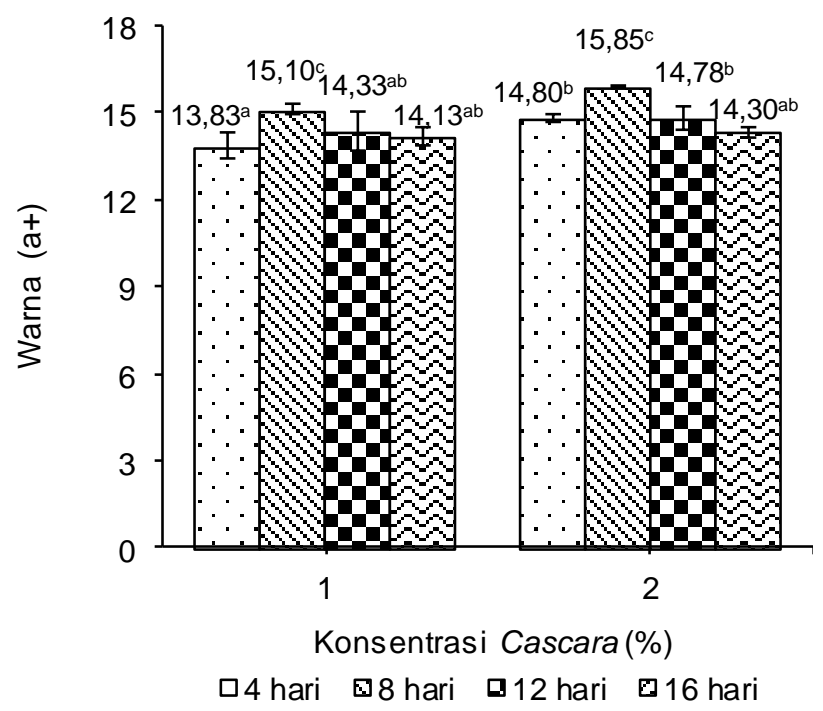

Gambar 5. Nilai warna (a+) kombucha cascara

\section{Nilai pH kombucha cascara}

Nilai pH kombucha cascara berkisar antara 3 sampai 3,75 (Gambar 7). Nilai pH kombucha yang aman dikonsumsi yaitu tidak boleh $<3$. Apabila nilai $\mathrm{pH}<3$ maka minuman kombucha perlu diencerkan terlebih dahulu sebelum dikonsumsi Nilai pH kombucha cascara yang dihasilkan masih dalam batas aman untuk dikonsumsi dan dapat diterima oleh tubuh.

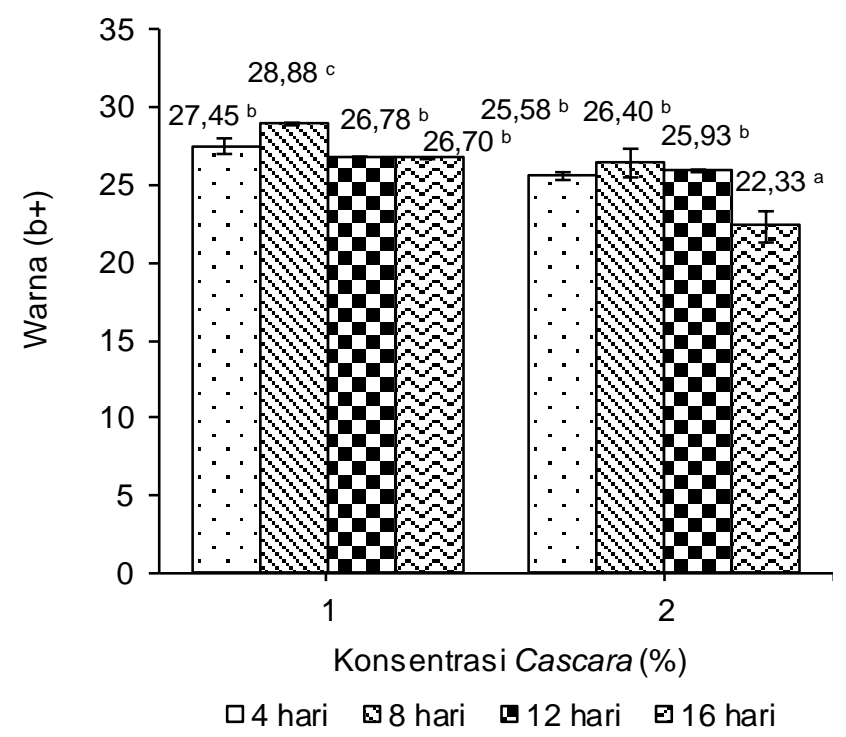

Gambar 6. Nilai warna (b+) kombucha cascara

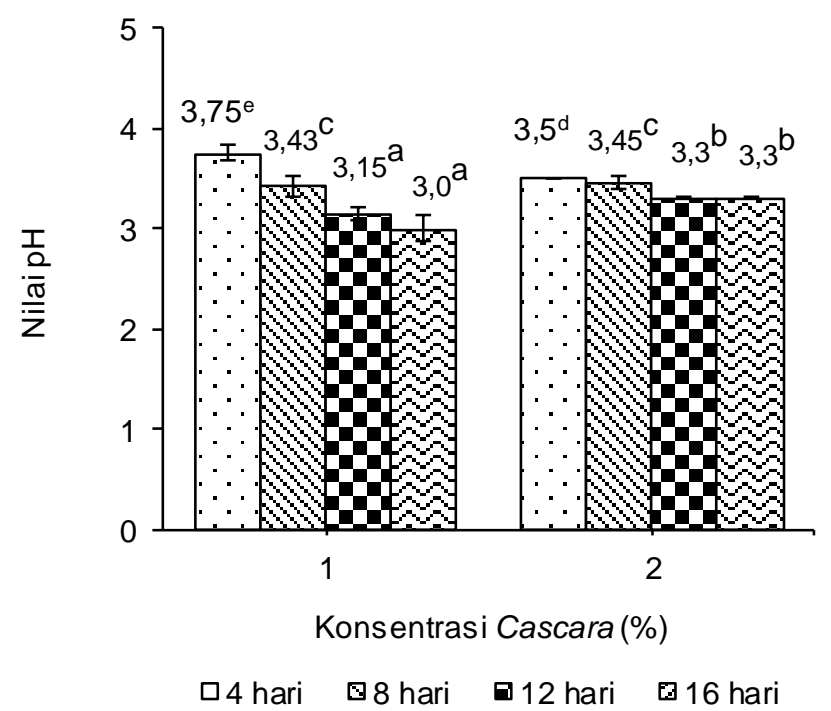

Gambar 7. Nilai pH kombucha cascara

Kombucha dengan penambahan cascara $1 \%$ memiliki $\mathrm{pH}$ lebih rendah dibandingkan kombucha dengan penambahan cascara $2 \%$. Hal ini diduga karena pada konsentrasi cascara $2 \%$ pertumbuhan mikroba kombucha terhambat dengan keberadaan senyawa bioaktif pada cascara, sehingga perom- 
bakan substrat menjadi asam-asam organik lebih rendah dan berakibat pada lambannya penurunan nilai pH. Menurut Nur et al. (2018), apabila kandungan senyawa bioaktif tinggi maka dapat memperlambat pertumbuhan mikroba. Semakin banyak penambahan cascara menyebabkan kandungan senyawa bioaktif seperti senyawa fenolik dan tanin semakin tinggi (Velićanski et al., 2014), sedangkan senyawa fenolik dan tanin memiliki efek sebagai antimikroba (Simanjuntak dan Mutiara, 2016; Ngajow et al., 2013).

Semakin lama fermentasi menunjukkan terjadinya penurunan $\mathrm{pH}$ kombucha cascara $(\alpha<0,05)$. Penurunan $\mathrm{pH}$ selama fermentasi mengindikasikan adanya aktivitas metabolisme dari bakteri dan khamir. Selama fermentasi terjadi perombakan sukrosa menjadi alkohol dan juga terbentuknya asam-asam organik lainnya oleh bakteri. Asam yang terbentuk akan melepaskan proton sehingga nilai $\mathrm{pH}$ menjadi rendah (Al-Yousef et al., 2017).

\section{Total asam tertitrasi kombucha cascara}

Total asam kombucha cascara berkisar antara 0,28 sampai 0,76\% (Gambar 8). Total asam pada kombucha dengan penambahan cascara $1 \%$ lebih tinggi dibandingkan dengan kombucha cascara $2 \%$. Seperti yang dijelaskan pada sub bab nilai $\mathrm{pH}$ bahwa keberadaan total asam tertitrasi berhubungan dengan pertumbuhan mikroba terutama bakteri asam laktat. Cascara memiliki kandungan senyawa aktif seperti kafein, tanin dan senyawa fenolik (Heeger et al., 2017; Velićanski et al., 2014). Keberadaan senyawa-senyawa aktif ini dapat menghambat pertumbuhan mikroorganisme, karena bersifat sebagai antimikroba (Simanjuntak dan Mutiara, 2016; Ngajow et al., 2013).

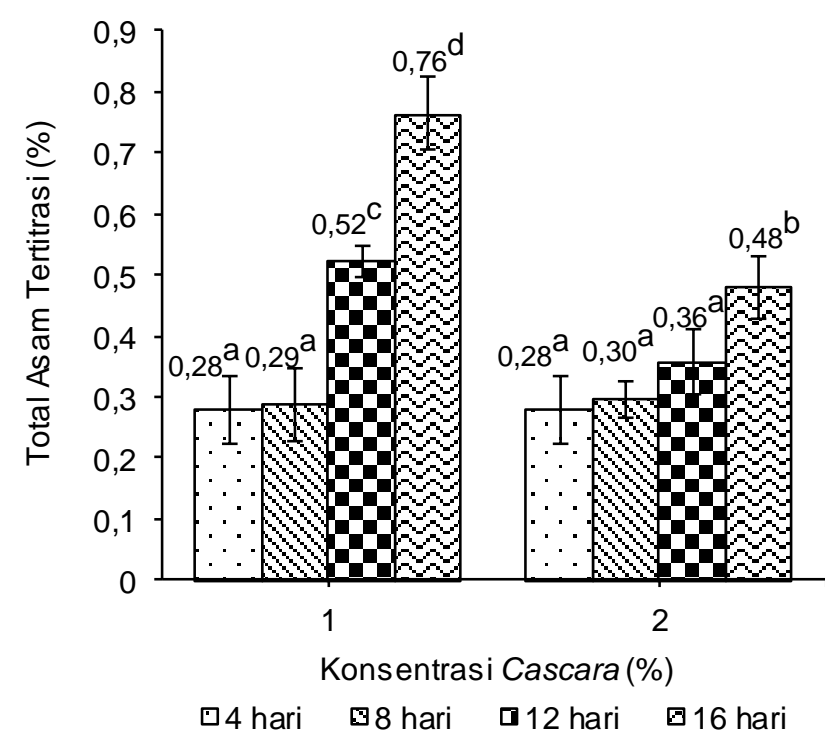

Gambar 8. Nilai total asam tertitrasi kombucha cascara
Peningkatan total asam pada kombucha merupakan hasil metabolisme bakteri yang menghasilkan asam-asam organik seperti asam asetat, asam glukonat, dan asam glukoronat (Jasman dan Widianto, 2012). Semakin lama fermentasi maka asam-asam organik yang terbentuk semakin meningkat dan terdeteksi sebagai total asam tertitrasi (Chakravorty et al., 2016). Galih (2015) melaporkan bahwa semakin lama fermentasi bisa menghasilkan total asam antara $0,5-2,0 \%$.

\section{Total senyawa fenolik kombucha cascara}

Total senyawa fenolik kombucha cascara berkisar antara 6,3 sampai 36,9 mg GAE/mL (Gambar 9). Total senyawa fenolik pada kombucha cascara $2 \%$ lebih tinggi dibandingkan kombucha cascara $1 \%$. Diketahui cascara mengandung senyawa fenolik seperti protocatechuic dan asam klorogenat (Heeger et al., 2016), sehingga semakin banyak penambahan cascara maka total fenolik yang terbentuk juga lebih banyak.

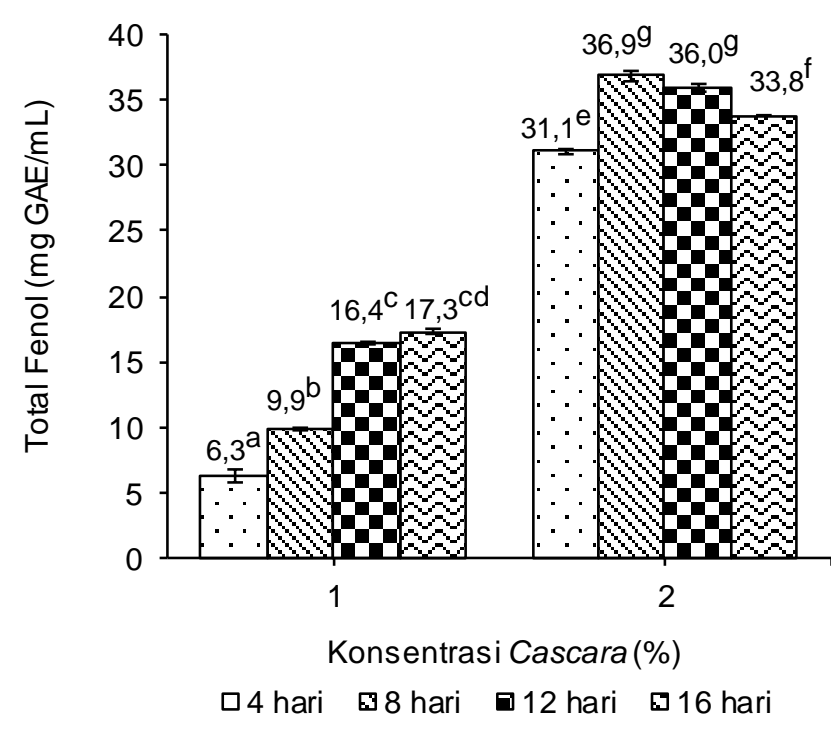

Gambar 9. Total senyawa fenolik pada kombucha cascara

Total fenolik pada kombucha cascara $1 \%$ meningkat dari fermentasi 4 hari hingga 16 hari, sedangkan pada perlakuan penambahan cascara $2 \%$ menunjukkan peningkatan hingga 12 hari fermentasi yang selanjutnya menurun. Hal ini diduga karena aktivitas enzimatis yang dihasilkan mikroba SCOBY kombucha dalam mendegradasi komponen matriks lainnya sehingga terbentuk senyawa fenolik (Bhattacharya et al., 2011). Seperti yang dilaporkan peneliti lainnya bahwa senyawa fenolik dapat terbentuk dari degradasi matriks komponen bahan lainnya akibat aktivitas enzimatis bakteri dan yeast pada kultur kombucha (Primurdia dan Kusnadi, 2014; Hernández et al., 2007). Kunaepah (2008) melapor- 
kan bahwa peningkatan kadar fenolik selama fermentasi juga terjadi pada fermentasi kefir susu kacang merah hingga $15 \%$. Hal ini diduga karena terjadi dekarboksilasi asam sinamat (asam ferulat dan asam kaumarat) membentuk 4-vinyl fenol. Dekarboksilasi asam sinamat menjadi vinyl fenol di karenakan aktivitas enzim vinyl fenol reduktase yang dihasilkan oleh khamir (Beek and Priest, 2000). Selain itu fermentasi oleh bakteri asam laktat Lactobacillus diketahui memiliki kemampuan mendegradasi asam ferulat dan asam sinamat menjadi senyawa fenol yaitu 4-vinyl fenol dan 4-vinyl guaiakol aktivitas enzim asam ferulat reduktase dan vinyl fenol reduktase (Gawel, 2004).

Protocatechuic dan asam klorogenat merupakan senyawa fenolik dari kelompok asam fenolat (Sakakibara et al., 2003). Vollmer et al. (2017) menyatakan degradasi asam klorogenat oleh mikroba mengubah asam klorogenat menjadi asam kafeat dan asam kafeat diuraikan menjadi asam sinamat. Asam kafeat merupakan senyawa fenolik golongan flavanoid. S. cerevisiae pada kultur kombucha mampu menghasilkan enzim fenol reduktase dan melakukan dekarboksilasi asam sinamat (Ayuratri dan Kusnadi, 2017). Asam sinamat seperti asam trans-4hidroksi metoksinamat (asam firulat) dan asam trans-4hidroksinamat (asam $p$-kaumarat) mengalami dekarboksilasi membetuk senyawa fenol yaitu 4vinyl guaiakol (4-VG) dan 4-vinyl fenol (4-VP) (Ayuratri dan Kusnadi, 2017; Curiel et al., 2010).

Adanya aktivitas enzim yang dihasilkan oleh mikroba yang digunakan sebagai starter dalam proses fermentasi. Senyawa fenolik yang terikat dengan komponen struktur dinding sel seperti selulosa, lignin, dan protein melalui ikatan ester akan mengalami sehingga terlepas menjadi asam fenolik bebas, sehingga dapat menyebabkan total senyawa fenoliknya akan mengalami peningkatan.

\section{Warna kombucha cascara}

Panelis memberi nilai warna kombucha cascara berkisar 1,4 hingga 4,47 artinya kombucha cascara yang dihasilkan memiliki warna kuning sampai sangat cokelat (Gambar 10). Warna cokelat yang ditimbulkan pada kombucha cascara dikarenakan adanya alfa diketon (Soeroso et al., 2017), dan senyawa lain yang berperan seperti tanin (Mawardi et al., 2016; Lisan, 2015) yang memberikan warna kuning kegelapan.

Sejalan dengan uji fisik warna, uji sensori juga menunjukkan warna kombucha cascara selama fermentasi berubah dari warna cokelat menjadi sedikit kuning. Hal ini mengindikasikan bahwa adanya aktivitas mikroba kultur kombucha mampu menyebabkan degradasi alfa diketon dan tanin. Anwar (2013) menjelaskan Acetobacter sp, Lactobacillus sp, dan Saccharomyces $\mathrm{sp}$ mampu menghasilkan enzim tannase untuk mendegradasi tanin selama fermen- tasi kombucha berlangsung. Selain itu, selama proses fermentasi menyebabkan alfa diketon dan tanin mengalami degradasi akibat penurunan $\mathrm{pH}$ sehingga warna kombucha cascara semakin cerah pudar (Wistiana dan Zubaidah, 2015; Ayuratri dan Kusnadi, 2017).

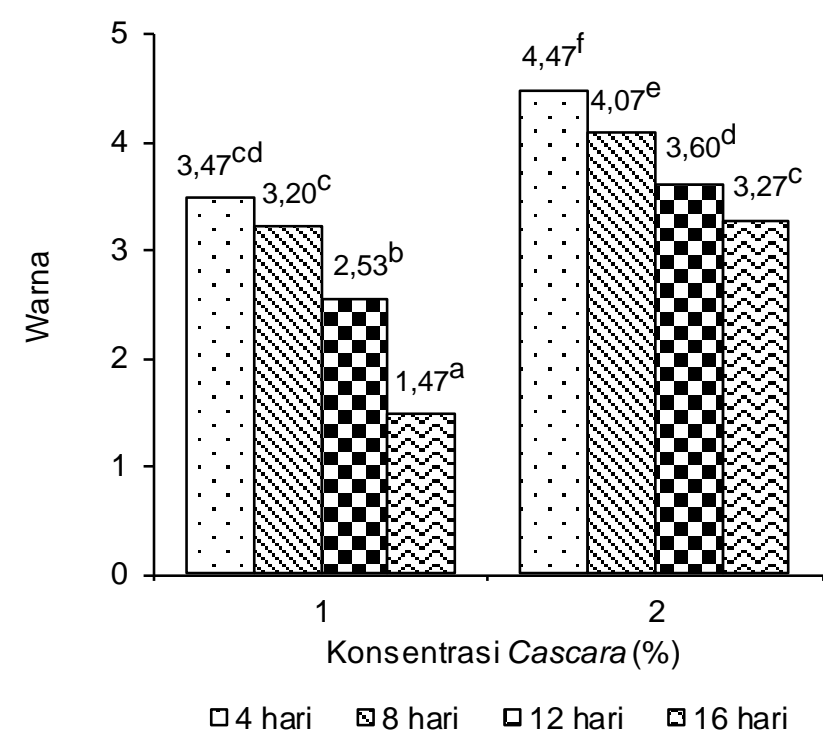

Gambar 10. Nilai sensori warna kombucha cascara

\section{Aroma asam kombucha cascara}

Panelis menilai kombucha cascara 1\% memiliki aroma asam yang muncul lebih kuat dibandingkan kombucha cascara 2\% (Gambar 11). Hasil tersebut sebanding dengan hasil uji total asam yang menunjukkan kadar total asam lebih tinggi pada kombucha cascara $1 \%$ dibandingkan dengan kombucha cascara $2 \%$, sehingga aroma asam yang muncul lebih kuat.

Semakin lama fermentasi aroma asam yang muncul juga semakin kuat akibat asam-asam organik yang terbentuk semakin banyak. Menurut Jasman dan Widianto (2012) selama fermentasi kombucha terjadi metabolisme gula oleh khamir dan bakteri yang menghasilkan asam-asam organik seperti asam asetat, asam glukonat, dan asam glukoronat.

\section{Kenampakan kombucha cascara}

Panelis menilai kombucha cascara $2 \%$ memiliki penampakan lebih keruh dibandingkan dengan kombucha cascara 1\% (Gambar 12). Hal ini diakibatkan oleh total padatan terlarut yaitu sukrosa yang ditambahkan dan kandungan zat terlarut pada cascara seperti asam-asam amino, pigmen, mineral, dan kafein (Heeger et al., 2017). Sintasari et al. (2014) mengungkapkan sukrosa merupakan komponen padatan terlarut yang dominan, namun disamping itu pigmen, vitamin, dan mineral juga menyumbang total padatan terlarut. 


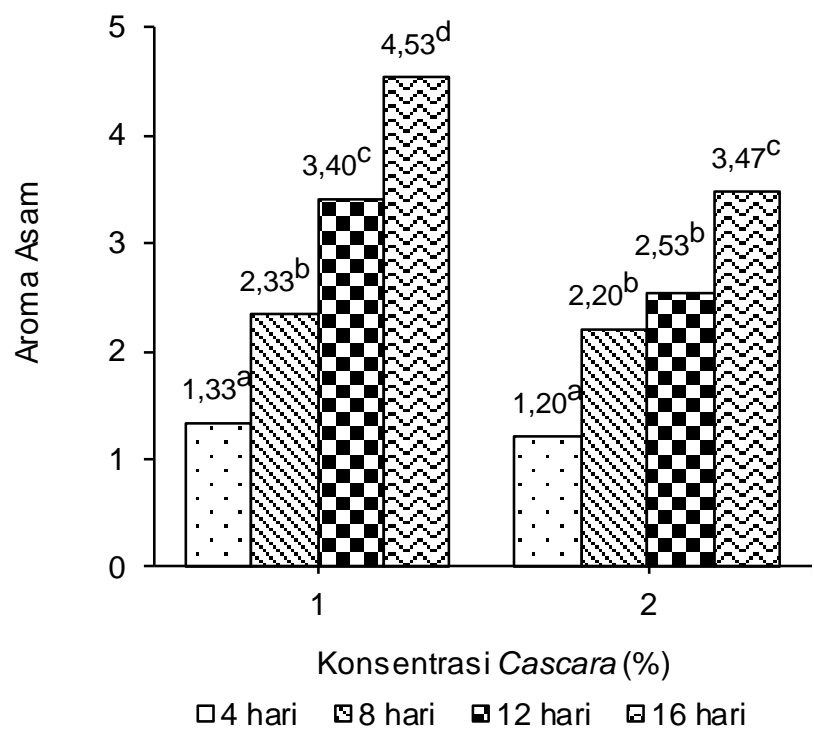

Gambar 11. Nilai aroma asam kombucha cascara

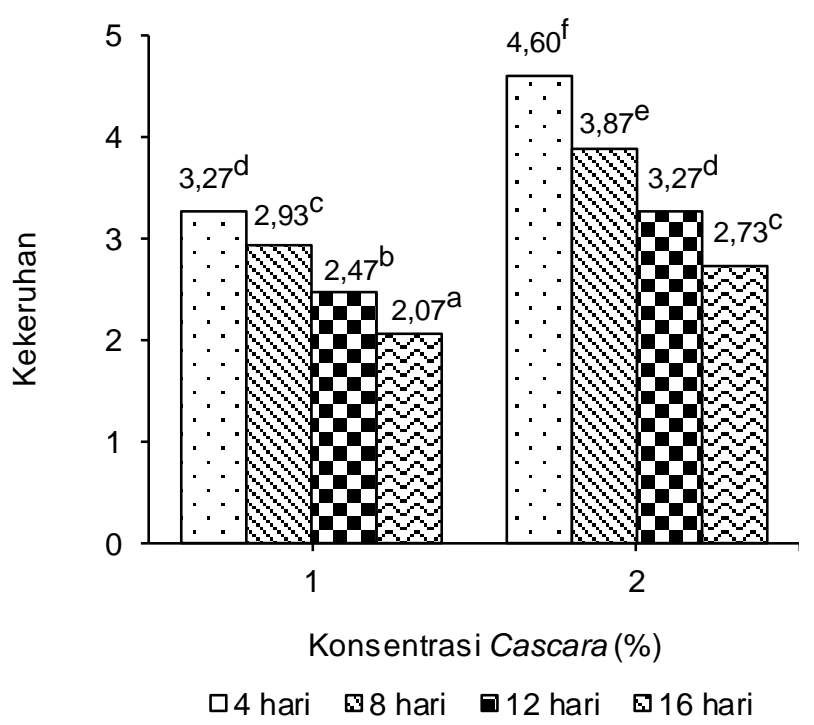

Gambar 12. Nilai kekeruhan kombucha cascara

Semakin lama fermentasi menghasilkan tingkat kekeruhan kombucha cascara yang lebih rendah. Hal ini dimungkinkan akibat aktivitas aktivitas mikroba yang mendegradasi substrat seperti gula dan kandungan zat terlarut pada cascara. Peningkatan mikroba mengakibatkan substrat semakin banyak yang digunakan untuk proses metabolisme mikroba sehingga total padatan semakin menurun (Napitupulu et al., 2015).

\section{Rasa pahit getir kombucha cascara}

Rasa pahit getir kombucha cascara berkisar antara 1,07 sampai 2,6 artinya kombucha cascara memiliki kisaran dari rasa tidak pahit sampai agak pahit getir (Gambar 13). Pada kombucha cascara
2\% kandungan kafein dan tanin lebih banyak, sehingga rasa pahit getir lebih kuat. Kandungan kafein dan tanin berperan dalam timbulnya rasa pahit getir (Oktadina et al., 2013; Kusumaningsih et al., 2015). Semakin lama fermentasi, kadar tanin dan kafein menurun akibat adanya aktivitas mikroorganisme dalam mendegradasi senyawa tersebut. Anwar (2013) menyatakan Acetobacter sp, Lactobacillus $\mathrm{sp}$, dan Saccharomyces sp menghasilkan enzim tannase untuk mendegradasi tanin selama fermentasi kombucha berlangsung.

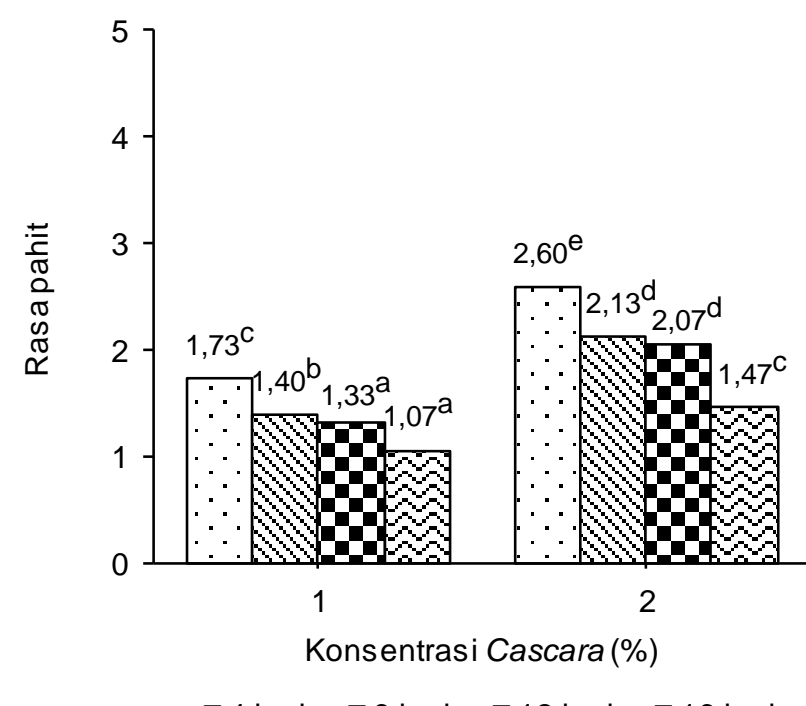

Gambar 13. Nilai rasa pahit kombucha cascara

\section{Rasa asam kombucha cascara}

Panelis menilai rasa asam pada kombucha cascara $1 \%$ lebih berasa asam dibandingkan konsentrasi 2\% (Gambar 14). Sebanding dengan hasil uji total asam, total asam pada kombucha cascara $1 \%$ lebih tinggi dibandingkan kombucha cascara $2 \%$, akibatnya rasa asam yang terbentuk juga lebih kuat. Selama fermentasi khamir dan bakteri melakukan metabolisme terhadap sukrosa dan menghasilkan asam-asam organik seperti asam asetat, asam glukoronat dan asam glukonat (Wistiana dan Zubaidah, 2015). Oleh karena itu, semakin lama fermentasi, asam yang terbentuk semakin banyak dan rasa asam yang muncul semakin kuat.

\section{Kombucha cascara terpilih}

Perlakuan terpilih pada pembuatan kombucha cascara ditentukan dengan uji efektivitas pembobotan 0-1. Kombucha terpilih yaitu kombucha cascara $1 \%$ dengan lama fermentasi 8 hari (Tabel 1).

Karakteristik kombucha terpilih memiliki nilai $\mathrm{pH}$ 3,43 , total asam tertitrasi $0,29 \%$, total fenolik $9,9 \mathrm{mg}$ $\mathrm{GAE} / \mathrm{mL}$, total padatan terlarut $11,25^{\circ}$ Brix, berat jenis $1,01 \mathrm{mg} / \mathrm{mL}$, viskositas $0,9 \mathrm{cP}$, kecerahan $\left(\mathrm{L}^{*}\right)$ 42,08, kemerahan $(\mathrm{a}+)$ 15,1, kekuningan $(\mathrm{b}+)$ 28,88, 
sensori warna 3,2 (agak cokelat), sensori aroma asam 2,3 (sedikit aroma asam), sensori kekeruhan 2,9 (cukup keruh), sensori rasa pahit 1,4 (sedikit rasa pahit), sensori rasa asam 2,8 (cukup rasa asam), sensori kesukaan 4,9 (netral).

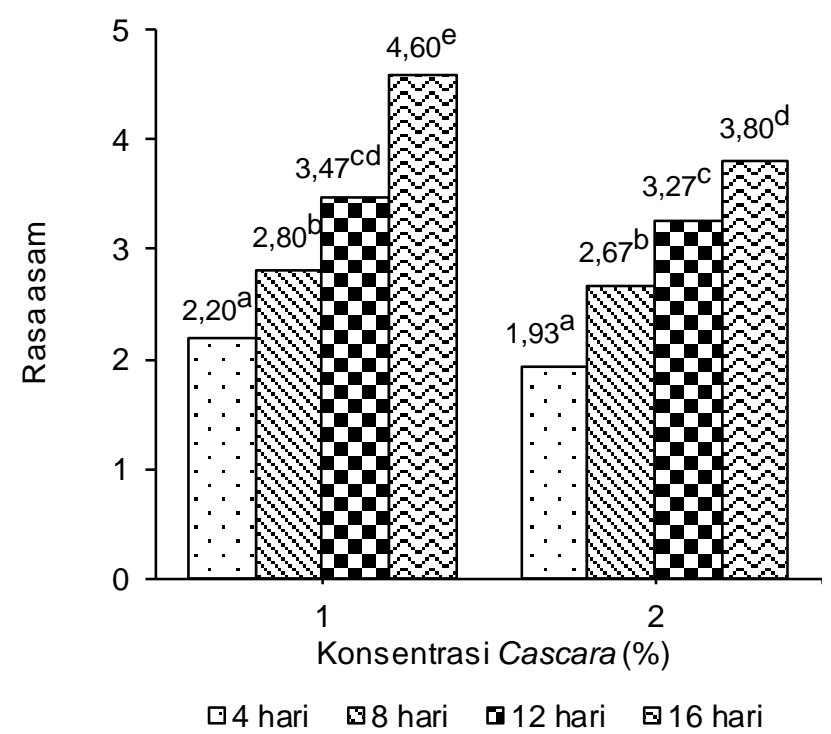

Gambar 14. Nilai rasa asam kombucha cascara

Tabel 1. Hasil uji efektivitas kombucha cascara

\begin{tabular}{ccc}
\hline $\begin{array}{c}\text { Konsentrasi } \\
\text { Cascara }(1 \% \text { b/v) }\end{array}$ & $\begin{array}{c}\text { Lama Fermentasi } \\
\text { (Hari) }\end{array}$ & $\begin{array}{c}\text { Nilai } \\
\text { Efektivitas }\end{array}$ \\
\hline 1 & 4 & 0,27 \\
1 & 8 & 1,99 \\
1 & 12 & 0,55 \\
1 & 16 & 0,60 \\
2 & 4 & 0,37 \\
2 & 8 & 0,69 \\
2 & 12 & 0,72 \\
2 & 16 & 0,80 \\
\hline
\end{tabular}

Kondisi fermentasi yang terindikasikan baik terjadi pada kombucha cascara $1 \%$ dibandingkan konsentrasi cascara $2 \%$. Hal tersebut yang memengaruhi cita rasa kombucha yang dihasilkan menjadi lebih disukai. Total fenolik pada lama fermentasi 8 hari menunjukkan total fenolik tertinggi. Total fenolik fermentasi 8 hari cenderung naik disebabkan selama proses fermentasi berlangsung mikroorganisme kultur kombucha melakukan metabolisme, hasil metabolisme tersebut yang mengakibatkan peningkatan fenolik pada kombucha. Hal ini sejalan dengan penelitian Suhardini dan Zubaidah (2016) bahwa total fenolik pada kombucha akan cenderung naik saat fermentasi 8 hari.

\section{KESIMPULAN}

Konsentrasi cascara dan lama fermentasi memberikan pengaruh terhadap karateristik kombucha cascara. Peningkatan penambahan cascara menghasilkan peningkatan total fenolik, total padatan terlarut, berat jenis, viskositas, dan warna $(\mathrm{a}+)$, namun terjadi penurunan nilai $\mathrm{pH}$ rendah, total asam tertitrasi, kecerahan (lightness/L), dan warna $(b+)$ sehingga warna sangat cokelat, sedikit beraroma asam, sangat keruh, dan terasa pahit. Semakin lama fermentasi menyebabkan peningkatan total asam tertitrasi, total fenolik, kecerahan $\left(L^{*}\right)$, dan warna $(\mathrm{b}+)$, namun terjadi penurunan nilai $\mathrm{pH}$, total padatan terlarut, berat jenis, viskositas, dan warna $(\mathrm{a}+)$ dengan nilai sensori untuk warna semakin kuning, beraroma asam, cukup keruh, sedikit pahit, beraroma asam. Perlakuan terpilih (terbaik) dihasilkan dari formula kombucha dengan penambahan $1 \%$ dan cascara lama fermentasi 8 hari.

\section{UCAPAN TERIMA KASIH}

Penulis mengucapkan terima kasih kepada Universitas Jember yang telah mendanai teknologi ini melalui pendanaan BOPTN Tahun 2018. Terima kasih juga disampaikan kepada Tim Pengabdian BOPTN Tahun 2018 Dr. Puspita Sari, S.TP, M.Phil dan Dr. Maria Belgis, S.TP, M.P. Terima kasih juga disampaikan kepada Program DAAD-UNEJ tahun 2019 yang telah mengirimkan Dr. Nurhayati, S.TP, M.Si untuk melakukan visiting laboratory di MRI Kiel Jerman untuk proses analisis lanjut produk komersial dan aplikasi pengembangan starter kombucha cascara untuk starter yoghurt. Terima kasih juga kepada Kemristek BRIN atas support penelitian lanjutan melalui PTM 2020 yaitu Pengembangan Starter Konsorsia Kombucha Cascara sebagai Minuman Fungsional Melalui Co-Culture Khamir.

\section{DAFTAR PUSTAKA}

Akbarirad M, Mazaheri AR, Pourahmad A, Mousavi K. 2017. Employing of the different fruit juices substrates in vinegar kombucha preparation. Curr Nutr Food Sci 13: 303-308. DOI: 10.2174/ 1573401313666170214165641.

Al-Yousef HM, Sawab A, Alruhimi M. 2017. Pharmacognostic studies on coffee Arabica L. husks: a brilliant source of antioxidant agents. European J Pharm Med Res 4: 86-92.

Anwar YAS. 2013. Prospek enzim tanase dalam pengembangan industri di Indonesia. J Pijar MIPA 8: 32-36. DOI: 10.29303/jpm.v8i1.58. 
Ayed L, Abid BS, Hamdi M. 2017. Development of a beverage from red grape juice fermented with the kombucha consortium. Annals Microbiol 67: 111-121. DOI: 10.1007/s13213-016-124 2-2.

Ayuratri MK, Kusnadi J. 2017. Aktivitas antibakteri kombucha jahe (Zingiber officinale) (Kajian varietas jahe dan konsentrasi madu). J Pangan Agroind 5: 95-107.

Azizah N, Al-Baarri AN, Mulyani S. 2012. Pengaruh lama fermentasi terhadap kadar alkohol, $\mathrm{pH}$, dan produksi gas pada proses fermentasi bioetanol dari whey dengan substitusi kulit nanas. J Aplikasi Teknologi Pangan 1: 72-77.

Battikh H, Bakhrouf A, Ammar E. 2012. Antimicrobial effect of kombucha analogues. LWT-Food Sci Technol 47: 71-77. DOI: 10.1016/j.Iwt.2011.12. 033.

Bayu MK, Nurwantoro, Risqiati H. 2017. Analisis total padatan terlarut keasaman kadar lemak dan tingkat viskositas pada kefir optima dengan lama fermentasi yang berbeda. J Teknol Pangan 1: 33-38.

Beek SV, Priest FG. 2000. Decarboxylation of substituted cinnamic acid by lactic acid bacteria isolated during malt whisky fermentation. Appl Environ Microbiol 2000: 5322-5328. DOI: 10. 1128/AEM.66.12.5322-5328.2000.

Bhattacharya S, Manna P, Gachhui R, Sil PC. 2011. Protective effect of kombucha tea against tertiary butyl hydroperoxide induced cytotoxicity and cell death in murine hepatocytes. Indian $J$ Exp Biol 49: 511-524.

Bhusari SI, Desai VD, Nalawade ML, Wadkar SS, Ghosh JS. 2013. Fermentation and characterization of wine from fruits of phoenix dactylifera, using Saccharomyces cerevisae NCIM3495. Int Food Res J 20: 3411-3415.

Chakravorty S, Semantee B, Antonis C, Writachit C, Debanjana B, Ratan G. 2016. Kombucha tea fermentation: Microbial and biochemical dynamics. Int J Food Microbiol 220: 63-72. DOI: 10. 1016/j.ijfoodmicro.2015.12.015.

Chu CS, Chen C. 2006. Effect of origin and fermentation time on the antioxidant activites of kombucha. Food Chem 98: 502-507. DOI: 10.1016/ j.foodchem.2005.05.080.

Curi PN, Aline BA, Bruna ST, Cleiton AN, Rafael P, Moacir P, Vanessa RS. 2017. Optimization of tropical fruit juice based on sensory and nutritional characteristics. Food Sci Technol 37: 308314. DOI: 10.1590/1678-457x.24716.

Curiel JA, Rodríguez H, Landete JM, de las Rivas B, Muñoz R. 2010. Ability of Lactobacillus brevis strains to degrade food phenolic acids. Food
Chem 120: 225-229. DOI: 10.1016/j.foodchem. 2009.10.012.

Direktorat Jendral Perkebunan. 2016. Statistik Perkebunan Indonesia 2015-2017 (kopi). Jakarta.

Falahuddin I, Ike A, Nurfadilah. 2017. Pengaruh proses fermentasi kombucha daun sirsak (Annona muricata L.) terhadap kadar vitamin C. J Biota 3: 90-95. DOI: 10.19109/Biota. ßi2. 1323.

Gawel R. 2004. Brettanomyces Character in Wine. The Australian Society of Wine Education National Convention. Hunter Valley, Australia. $4^{\text {th }}-$ $6^{\text {th }}$ of june 2004. http://www.aswe.org.au. [19 Mei 2008].

Heeger A, Agnieszka KC, Ennio C, Wilfried A. 2017. Bioactives of coffee cherry pulp and its utilisation for production of cascara beverage. Food Chem 221: 969-975. DOI: 10.1016/j.foodchem. 2016.11.067.

Hernández A, Martin A, Aranda E, Pérez-Nevado $F$, Córdoba MG. 2007. Identification and characterization of yeast isolated from the elaboration of seasoned green table olives. Food Microbiol 24: 346-351. DOI: 10.1016/j.fm.2006.07.022.

Howard BM, Hung YC, McWatters K. 2011. Analysis of ingredient functionality and formulation optimization of pasta supplemented with peanut flour. J Food Sci 76: 40-47. DOI: 10.1111/j.17 50-3841.2010.01886.x.

[ICO]. 2017. Record exports for coffee year 2016/17.http://www.ico.org/documents/cy201718/cmr-1017-e.pdf [23 Mei 2018].

Jasman J, Prijambada ID, Hidayat C, Widianto D. 2012. Selection of yeast strains for ethanol fermentation of glucose-fructose-sucrose mixture. Indonesian J Biotechnol 17: 114-120. DOI: 10.22146/ijbiotech. 16001.

Kunaepah U. 2008. Pengaruh Lama Fermentasi dan Konsentrasi Glukosa Terhadap Aktivitas Antibakteri, Polifenol Total dan Mutu Kimia Kefir Susu Kacang Merah. [Tesis]. Semarang: Fakultas Teknologi Pangan, Universitas Diponegoro.

Kusumaningsih T, Nur JA, Suci W, Dewi RT, Wardani, Khoirul F. 2015. Pengurangan kadar tanin pada ekstrak Stevia rebaudiana dengan menggunakan karbon aktif. Alchemy-J Penelitian Kimia 11: 81-89.

Lisan FR. 2015. Penentuan jenis tanin secara kualitatif dan penetapan kadar tanin dari serabut kelapa (Cocos nucifera L.) secara permanganometri. Calyptra-J IImiah Mahasiswa Universitas Surabaya 4: 1-16.

Mawardi YSA, Yoyok BP, Bhakti ES. 2016. Kadar air, tanin, warna dan aroma off-flavour minuman fungsional daun sirsak (Annona muricata) dengan berbagai konsentrasi jahe (Zingiber 
officinale). J Aplikasi Teknol Pangan 5: 94-98. DOI: $10.17728 /$ jatp. 179.

Muzaifa M, Hasni D, Arpi N, Sulaiman MI, Limbong MS. 2019. Kajian pengaruh perlakuan pulp dan lama penyeduhan terhadap mutu kimia teh cascara. J Teknol Pertanian Andalas 23: 136142.

Napitupulu MOW, Setyohadi, Lubis LM. 2015. Pengaruh variasi konsentrasi gula sukrosa dan lama fermentasi terhadap pembuatan kopi kombucha. J Rekayasa Pangan dan Pert 3: 316322.

Nur YM, Indrayati S, Periadnadi, Nurmiat. 2018. Pengaruh penggunaan beberapa jenis ekstrak tanaman beralkaloid terhadap produk teh kombucha. J Biol UA 6: 55-62. DOI: 10.25077/jbio ua.6.1.55-62.2018.

Nuraini N, Marlid, Y, Mirzah M, Disafitri R, Febrian R. 2015. Peningkatan kualitas limbah buah kopi dengan phanerochaete chrysosporium sebagai pakan alternatif. J Peternakan Indonesia 17: 143-150. DOI: 10.25077/jpi.17.2.143-150.2015.

Ngajow M, Jemmy A, Vanda S. K. 2013. Pengaruh antibakteri ekstrak kulit batang matoa (Pometia pinnata) terhadap bakteri Staphylococcus aureus secara in vitro. J MIPA Unsrat 2: 128132.

Nguyen NK, Nguyen PB, Nguyen HT, Le PH. 2015. Screening the optimal ratio of symbiosis between isolated yeast and acetic acid bacteria strain from traditional kombucha for high-level production of glucuronic acid. LWT-Food Sci Technol 64: 1149-1155. DOI: 10.1016/j.Iwt.20 15.07.018.

Oktadina FD, Argo BD, Hermanto MB. 2013. Pemanfaatan nanas (Ananas comosus L. Merr) untuk penurunan kadar kafein dan perbaikan citarasa kopi (coffea sp) dalam pembuatan kopi bubuk. J Keteknikan Pertanian Tropis Biosistem 1: 265-273.

Pabari S. 2014. Cascara, the coffee cherry tea with a how to brew guide. Roasters pack. https://the roasterspack.com/blogs/news/14918821-casca ra-the-coffee-cherry-tea-with-a-how-to-brew-gui de. [25 Desember 2017].

Pratiwi A, Elfita, Aryawati R. 2012. Pengaruh waktu fermentasi terhadap sifat fisik dan kimia pada pembuatan minuman kombucha dari rumput laut Sargasssum sp. Maspari J 4: 131-136.

Primurdia EG, Kusnadi J. 2014. Aktivitas antioksidan minuman probiotik sari kurma (Phoenix dactilyfera L.) dengan isolat $L$. plantarum dan $L$. casei. J Pangan Agroind 2: 98-109.
Pure AE, Pure ME. 2016. Antioxidant, antibacterial and color analysis of garlic fermented in kombucha and red grape vinegar. Applied Food Biotechnol 3: 246-252.

Sakakibara H, Honda $Y$, Nakagawa S, Ashida H. 2003. Simultaneous determination of all polyphenols in vegetables, fruits, and teas. J Agric Food Chem 51: 571-581. DOI: 10.1021/jf02092 61.

Setianto YC, Pramono YB, Mulyani S. 2014. Nilai $\mathrm{pH}$, viskositas, dan tekstur yogurt drink dengan penambahan ekstrak salak pondoh (Salacca zalacca). J Aplikasi Teknol Pangan 3: 110-113.

Simanjuntak RJD, Mutiara H. 2016. Pengaruh pemberian teh kombucha terhadap pertumbuhan Salmonella typhi. Med J Lampung University 5: 48-54.

Sintasari RA, Kusnadi J, Ningtyas DW. 2014. Pengaruh penambahan konsentrasi susu skim dan sukrosa terhadap karakterisik minuman probiotik sari beras merah. J Pangan Agroind 2: 6575.

Soeroso EG, Lestario LN, Martono Y. 2017. Penambahan gula dapat meningkatkan stabilitas warna ekstrak antosianin buah murbei hitam yang terpapar cahaya fluoresens. J Teknol Industri Pangan 28: 62-69. DOI: 10.6066/jtip. 2017.28.1.62

Suhardini PN, Zubaidah E. 2016. Studi aktivitas antioksidan kombucha dari berbagai jenis daun selama fermentasi. J Pangan Agroind 4: 221229.

Sun TY, Li JS, Chen C. 2015. Effects of blending wheatgrass juice on enhancing phenolic compounds and antioxidant activities of traditional kombucha beverage. J Food Drug Anal 23: 709-718. DOI: 10.1016/j.jfda.2015.01.009.

Velićanski SA, Cvetković DD, Šaponjac VTT, Vulić JJ. 2014. Antioxidant and antibacterial activity of the beverage obtained by fermentation of sweetened lemon balm (Melissa officinalis L.) tea with symbiotic consortium of bacteria and yeasts. J Food Tech Biotech 52: 420-429. DOI: 10.17113/ftb.52.04.14.3611.

Vollmer M, Schröter D, Esders S, Neugart S, Farquharson FM, Duncan SH, Schreiner M, Louis $P$, Maul R, Rohn S. 2017. Chlorogenic acid versus amaranth's caffeoylisocitric acid-Gut microbial degradation of caffeic acid derivatives. J Food Res Int 100: 375-384. DOI: 10.1016/j.foodres. 2017.06.013. 
Wistiana D, Zubaidah E. 2015. Karakteristik kimiaw dan mikrobiologis kombucha dari berbagai daun tinggi fenol selama fermentasi. J Pangan Agroind 3: 1446-1457.

Wulandari A. 2018. Pengaruh Lama Waktu Fermentasi Kombucha Teh Hijau Daun Jati (Tectonagrandis Linn.) terhadap Kadar Tanin Total dan Total Asam Tertitrasi (TAT). [Skripsi]. Yogyakarta: Fakultas Keguruan dan IImu Pendidikan, Universitas Sanata Dharma.

Yavari N, Mazaheri-Assadi M, Mazhari Z, Moghadam M, Larijani K. 2018. Glucuronic acid rich kombucha-fermented pomegranate juice. J Food Res 7: 61-69. DOI: 10.5539/jfr.v7n1p61.
Zubaidah E, Saparianti E, Hindrawan J. 2012. Studi aktivitas antioksidan pada bekatul dan susu skim terfermentasi probiotik (Lactobacillus plantarum B2 dan Lactobacillus acidophillus). J Teknol Pertanian 13: 111-118.

Zubaidah E, Dewantari FJ, Novitasari FR, Srianta I, Blanc PJ. 2018. Potential of snake fruit (Salacca Zalacca (Gaerth.) Voss) for the development of a beverage through fermentation with the kombucha consortium. Biocatal Agric Biotechnol 13: 198-203. DOI: 10.1016/j.bcab. 2017.12.012. 